\title{
CARTA DOS EDITORES
}

Apresentamos o terceiro número do sexto volume da Revista de Estudos Empíricos em Direito, periódico científico quadrimestral de iniciativa do Instituto Rede de Pesquisa Empírica em Direito, que vem se consolidando como um periódico especializado em pesquisas empíricas e multidisciplinares relativas ao direito. No entanto, depois de oito anos de atividades ininterruptas, passa, agora, por uma reestruturação significativa nas suas políticas de ética e nas suas regras de submissão com vistas a elevar seu padrão de qualidade.

Com relação à política de ética, procuramos explicitar as regras a serem seguidas por editores, assistentes, pareceristas e autores no site de nosso periódico. Expor, de forma transparente e clara, as políticas de ética no processo de submissão, avaliação e publicação de artigos no periódico é um passo relevante rumo à qualidade tanto da natureza das submissões quanto do protocolo editorial'

Além disso, é relevante destacar que o software OJS (Open Journals System) de nosso periódico foi devidamente atualizado para a versão 3.1.2.1 e, agora, possui um suporte permanente para que possamos oferecer um serviço de qualidade em todas as fases do processo editorial.

Quanto às regras de submissão, passamos a ter como requisito para submissão de artigos no periódico o título de doutor para, ao menos, um dos coautores do artigo. isto para que se intensifiquem as submissões de artigos fruto de pesquisas empíricas derivadas de um grupo heterogêneo composto de pesquisadora(e)s em vários níveis de forma- ção, de modo a deixar clara a nossa busca por relatórios parciais e finais de uma pesquisa empírica de qualidade a qual decorra de uma atividade de investigação colaborativa. É importante ressaltar ainda que todos os artigos aqui publicados passam por rigoroso processo de dupla avaliação cega por pares (double blind peer review), de modo que não se trata de apenas verificar o requisito formal da titulação, mas todo o processo de construção do artigo científico a partir da participação de toda(o)s na elaboração do relato parcial ou final da pesquisa empírica em direito, conforme explicitado em nossa atual política de ética.

Ainda, gostaríamos de agradecer a contribuição de Inês Tavares e Amanda Evelyn Lima que agora se despedem do corpo editorial da nossa Revista, após terem demonstrado competência e eficiência na boa execução de suas funções de assistente editorial. A ambas, o nosso reconhecimento pelo bom trabalho realizado. Aproveitamos, ainda, para desejar boas vindas às novas e aos novos assistentes editoriais, Alan Rossi Silva, Elora Raad Fernandes, Felipe César de Andrade, João Vitor Freitas Moreira, Lorena Abbas da Silva, Nicollas Rodrigues Castro, Susana van der Ploeg e Thiago Fillipo Silva Jorge, os(as) quais têm diante de si a tarefa de manter a qualidade e aprimorar a eficiência de nosso periódico.

Enfim, registramos nosso mais caloroso agradecimento a toda(o)s as pareceristas e revisora(e)s sem a(o)s quais esse número não teria sido possível.

\section{Boa leitura!}

Fernando de Castro Fontainha Marcos Vinício Chein Feres

EDITORES 


\section{LETTER FROM THE EDITORS}

We are pleased to introduce the third issue of the sixth volume of the Brazilian Journal of Empirical Legal Studies, a scientific journal of the Brazilian Network of Empirical Legal Studies, which is consolidating as a specialized journal on empirical research applied to the realm of Law. However, after eight years of uninterrupted publishing activities, the publication is now passing through significant restructuration of the policies regarding ethics and the rules of submission in order to raise the qualitative standards of our scientific Journal.

As far as the policies regarding ethics are concerned, our goal is to clearly lay out all the rules to be followed by editors, assistants, reviewers and authors on the site of our journal. Enumerating, with transparency and clarity, these policies in the process of submitting, evaluating and publishing articles in this journal are paramount for a maintaining high standards, concerning the nature of the submissions and editorial protocol'.

Moreover, it is relevant to emphasize that the OJS (Open Journals System) software of our Journal has been fully updated to version 3.1.2.1 and, now, there is permanent technical support to offer better qualitative service at all of the stages of the editorial process.

Regarding the submission rules, it is now a pre-requisite when submitting an article, that at least one of the authors has to have a Doctorate. This measure aims to encourage the submission of articles derived from empirical research carried out by a heterogenous team, consisting of a junior or senior researcher

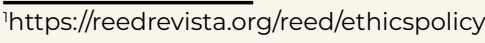

(PhD), graduate and/or undergraduate students. In fact, this is to prioritize our search for partial and final reports on empirical legal research derived from collaborative investigation. Furthermore, every article submitted to this journal must undergo a rigorous double-blind peer review. During this process, it is not simply a matter of verifying the formal requisite of a $\mathrm{PhD}$ qualification, but to check if the elaboration of the article complies with the effective participation of everyone involved in the research itself, as it is explicitly expressed in our policies regarding ethics.

In addition, we would like to thank the contribution of Inês Tavares and Amanda Evelyn Lima who, in being part of our Editorial Board, have been competent and efficient in the execution of their daily functions as editorial assistants. To both of them, our sincere acknowledgment of the good work done. We would also like to welcome the new editorial assistants, Alan Rossi Silva, Elora Raad Fernandes, Felipe César de Andrade, João Vitor Freitas Moreira, Lorena Abbas da Silva, Nicollas Rodrigues Castro, Susana van der Ploeg e Thiago Fillipo Silva Jorge, who will commit themselves to maintain the quality and to enhance the efficiency of our Journal.

Finally, we would like to warmly thank all reviewers and text revisers, without whom this issue would not have been possible to publish.

\section{Happy reading!}

Fernando de Castro Fontainha Marcos Vinício Chein Feres

EDITORS 